\title{
COMPETITIVENESS ANALYSIS OF TOURISM IN THE EUROPEAN UNION AND IN THE SLOVAKIA
}

\author{
L'udmila BEDNÁROVÁ \\ University of Prešov, Faculty of Management, Department of Finance \\ Konštantínova 16, o8o o1 Prešov, Slovakia, e-mail: ludmila.bednarova@unipo.sk

\section{Dana KISEL'ÁKOVÁ} \\ University of Prešov, Faculty of Management, Department of Finance \\ Konštantínova 16, o8o o1 Prešov, Slovakia, e-mail: dana.kiselakova@unipo.sk \\ Erika ONUFEROVÁ \\ University of Prešov, Faculty of Management, Department of Finance \\ Konštantínova 16, o8o o1 Prešov, Slovakia, e-mail: erika.onuferova@smail.unipo.sk
}

\begin{abstract}
Citation: Bednárová, L., Kiseláková, D., \& Onuferová, E. (2018). COMPETITIVENESS ANALYSIS OF TOURISM IN THE EUROPEAN UNION AND IN THE SLOVAKIA. GeoJournal of Tourism and Geosites, 23(3), 759-771. https://doi.org/10.30892/gtg.23312-326
\end{abstract}

\begin{abstract}
In the last three decades, tourism has become one of the most dynamic sectors in many countries, providing significant benefits to their economies. Consequently, countries are interested in developing this sector with the aim of increasing tourists and visitors inflow in to their countries and the corresponding financial contribution to the national budget and other economic benefits this would attract. The main objective of this study is to analyse the competitiveness position of tourism in European Union (EU) countries for the period of 2015 and 2017 based on the Travel \& Tourism Competitiveness Index (TTCI). The study also identifies the factors that impacts countries' competitive positions with a focus on Slovakia. Using cluster analysis for three selected macroeconomic indicators tourism revenues, tourism expenditures and gross domestic product per capita in tourism - the study also includes an analysis of the competitiveness of the EU countries based on own assessment. Results shown that the TTCI is not influenced by revenues, expenditures or gross domestic product in tourism. So, Slovakia should focus on improving such factors as efficiency of legal framework in settling disputes; the effect of taxation on incentives on work hiring and firing practices; government prioritization of travel and tourism industry and effectiveness of marketing and branding to attract tourists.
\end{abstract}

Key words: Tourism competitiveness, European Union, Slovak Republic, Travel \& Tourism Competitiveness Index, Cluster analysis

\footnotetext{
* Corresponding author
} 


\section{INTRODUCTION}

Tourism has become one of the largest contributors to the world and European economy with increasing impacts at both national and global levels. Measuring the competitiveness of tourism using specific defined factors originated at the beginning of the $21^{\text {st }}$ century and created the possibility of inter-country comparisons. Competitiveness monitoring of the national economies within the international tourism market is executed by the World Economic Forum (WEF), the Organization for Economic Cooperation and Development (OECD) and the European area is monitored by the European Union Statistical Office (Eurostat). The WEF began to process the tourism competitiveness data of individual countries in 2007. The Travel \& Tourism Competitiveness Index (TTCI) was created to measure travel \& tourism competitiveness and it is published every two years. The OECD uses its own indicators to measure the tourism competitiveness. The several differences are between these indicators. The main differences consist in the number of evaluated indicators, but primarily in the pursue objectives (World Economic Forum, 2018; Organization for Economic Co-operation and Development, 2018; European Union Statistical Office, 2018). So, the main objective of this study is to analyse the competitiveness position of tourism in European Union (EU) with a focus on Slovakia countries for the period of 2015 and 2017 based on the TTCI.

\section{LITERATURE REVIEW}

At present, the issue of tourism competitiveness occupies a key niche in economic research in many countries. This is, because competitiveness is still one of the key performance assessment criteria for economies. In the past 20 years travel \& tourism have proven to be significant drivers of economic growth, contributing over $10 \%$ to global GDP and accounting for 1 in 10 jobs on the planet according to international institutions (the World Economic Forum, 2018; the Eurostat, 2018). The goal of achieving a sustainable and inclusive travel \& tourism industry is very actual now, and this industry has been proactive in its commitment to set targets (to increase financial contribution to the national budget and to increase number of tourists and visitors inflow into country). Analysis of global trends also confirms significant progress in travel and tourism globally. Despite slow economic growth in advanced economies, growing global competitiveness and interdependence, and political tensions in many regions, the travel \& tourism sector still accounts for a large part of the global economy (the World Economic Forum, 2018).

Many empirical studies have evaluated countries' tourism competitiveness based on international indexes (Cibinskienea \& Snieskieneb, 2015; Hanafiah et al., 2014; Nica, 2015; Xing et al., 2014; Krstic et al., 2016) with a number of these studies focusing on the key determinants of competitiveness in the tourism sector (Kolosinska et al., 2018; Barbosa et al., 2010). An alternative view to analysing tourism competitiveness was proposed by Gabor et al., (2012). According to the paper, the rule in attracting tourists as well as domestic tourism development and support are based on microeconomic strategies and especially on national strategies in the tourism sector. Socio-economic and government policy differences were highlighted based on world countries ranking and the authors explore the statistical significance of these differences. Statistical analysis showed that there exist significant similarities and differences among EU countries. In another study, Cvelbar et al., (2015) measured total tourism contribution to GDP per employee in tourism - in order to examine country competiveness. Study findings demonstrated that tourism specific factors, such as tourism infrastructure and destination management, are the major competitiveness drivers in developing countries, while destination competitiveness in developed countries depends on tourism specific factors such as general infrastructure, macro-environment and business environment. In another study, 
Kubickova \& Li (2017) investigate the role of government in tourism competitiveness, exploring the interrelationship between the two based on the Tourism Area Life Cycle model. They argued that tourism competitiveness is influenced not only by the governments' decisions but also by the stage of tourism development of the country. Countries characterized as "tourism-dependent" demonstrated higher levels of government engagement than those less dependent on tourism. Khan et al. (2017) carried out a more in-depth analysis of the individual indicators of TTCI. They examined the impact of air transportation, railways transportation, travel and transport services on international inbound and outbound tourism in a panel of 19 tourists - oriented countries. Regression results showed that the presence of air transportation, railways transportation, and trade openness positively affect inbound tourism index, while travel and transport services negatively affect tourism competitiveness index. The study also emphasized the importance of the transportation sector in promoting tourism worldwide. In a similar study, Krstic et al. (2016) focused on analyzing the determinants of competitiveness in the travel \& tourism sector in Central and Eastern European (CEE) countries. The stated aim of the study was to explore the critical determinants of competitiveness in the travel \& tourism sector in these CEE countries.

Indicators such as cultural resources and business travel, air transport infrastructure, natural resources, ground and port infrastructure, and tourist service infrastructure were indicated as priority areas for improvement in the CEE countries competitiveness. According to Butnaru \& Niță (2016), the potential of the Travel \& Tourism sector stems from its contribution to the achievement of strategic EU objectives such as: sustainable development, economic development, human resources development, economic and social cohesion. The Travel \& Tourism sector is closely linked to many others economic sectors such as retailing, agriculture and construction, and therefore has significant potential to generate positive externalities on the remainder of the economic system (Kadiyali \& Kosová, 2013; Li, et al., 2016) and hence on the GDP (Čerović et al., 2016). According to Baiburiev et al. (2018), the economic contribution of tourism is felt in direct (production) routes, indirect (jobs) routes and induced (taxes) routes. Tatar, et al., (2018) also emphasis the tourist guides' role - as a mediator between demand and supply, as well as between tourist and local collectivities in the support of local economy and sustainable tourism development.

\section{TOURISM COMPETITIVENESS}

Tourism competitiveness is a complex issue and includes a wide range of objective and subjective factors. The identification of key factors representing countries' competitiveness of tourism has been realised by many authors. The measurement of the tourism competitiveness is complicated process. For that reason, various organizations are devoted to tourism competitiveness evaluation. In the next section of this study we mention two organizations that are devoted measuring tourism's competitiveness - assessment of the WEF based on the TTCI indicator and the OECD index based on own assessment tools.

\section{The Travel \& Tourism Competitiveness Index (TTCI)}

The WEF has edited the national tourism competitiveness data since 2007 in the Travel \& Tourism Competitiveness Report published every two years. There are several partner institutions working together to develop this index, including the United Nations World Tourism Organization (UNWTO), the World Travel \& Tourism Council (WTTC), the International Air Transport Association (IATA), the International Union for Conservation of Nature (IUCN), and others private companies. The aim of the TTCI "is to provide a comprehensive strategic tool for measuring the set of factors and policies that enable the sustainable development of the travel \& tourism sector, which in turn, 
contributes to the development and competitiveness of a country" (The Travel \& Tourism Competitiveness Report, 2017). The WEF regularly updates this index to respond to changing conditions. In the last revision, the number of sub-indexes and indicators increased. The latest TTCI indicator consists of 14 pillars, merged into 4 sub-indexes comprising of 90 indicators distributed among the different pillars (Figure 1).

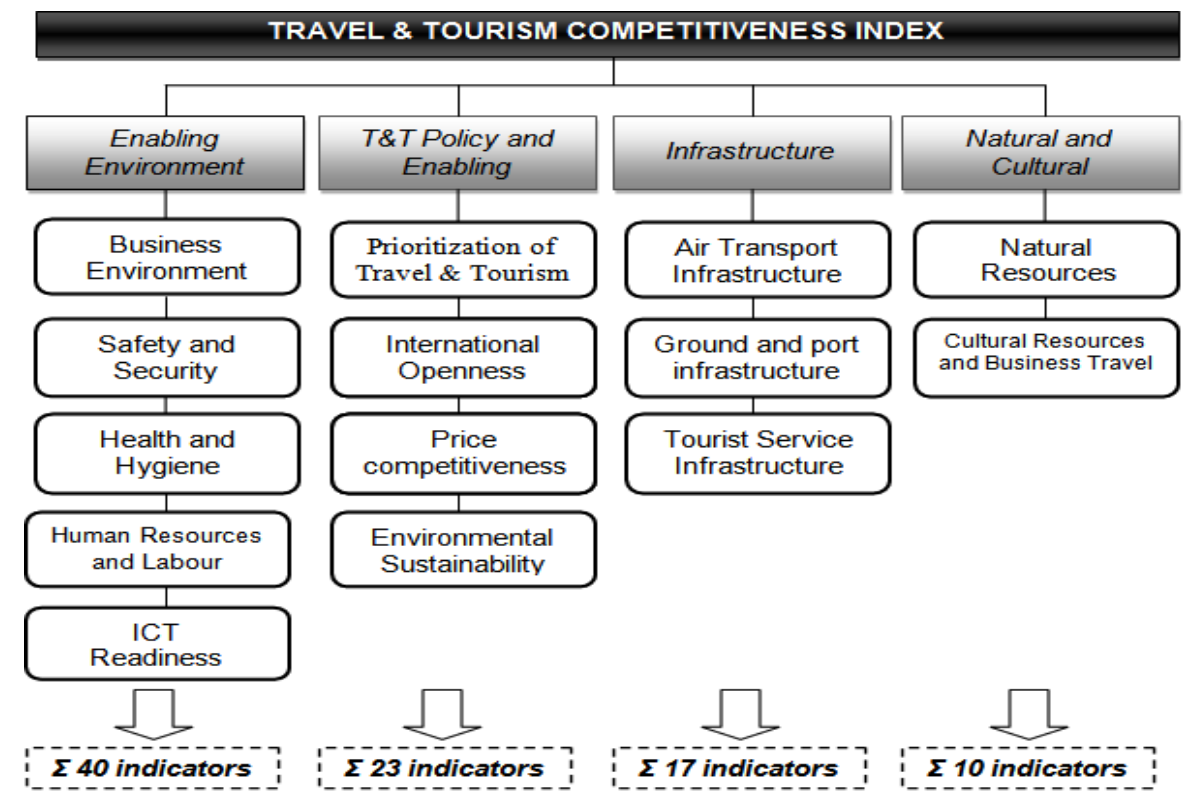

Figure 1. The Travel \& Tourism Competitiveness Index 2017 framework (Source: WEF, The Travel \& Tourism Competitiveness Report, 2017)

Two-thirds of the data set for the TTCI indicator are statistical data from international organizations, with the remaining third based on survey data from The World Economic Forum's annual Executive Opinion Survey which is used to measure concepts that are qualitative in nature carried out among over 15,000 business executives and business leaders annually in all the economies included in assessment. Data are ranked in scale 1 to 7 , where 7 means the best performing. The standard formula for converting each hard data indicator to 1 to 7 scale is as follows (WEF, The Travel \& Tourism Competitiveness Report, 2017):

$$
6 \mathrm{x}\left(\frac{\text { country score }- \text { sample minimum }}{\text { sample maximum }- \text { sample minimum }}\right)+1
$$

The sample minimum and sample maximum are the lowest and highest scores of the overall sample, respectively. The values of individual indicators comprise of such calculated data. The total pillar value is calculated by the arithmetic average of the indicators and the sub-indexes value is determined by the arithmetic average of all pillars in the given subindex. The overall TTCI indicator is calculated as the arithmetic average of all sub-indexes.

\section{OECD Index}

The OECD's work identifies a set of indicators that can be applied within an overall framework to assess countries' competitiveness. The OECD approach creates a limited set of meaningful and robust indicators useful for governments to evaluate and measure tourism competitiveness of their countries over time and to guide them in their policy 
choices. The aim of the framework is not to produce an index or a ranking of the most competitive countries, but to provide a tool guide for countries to analyse tourism competitiveness and inform policy (Dupeyras \& MacCallum, 2013). The OECD places emphasis on the implementation of tourism policy and makes it possible to assess current policy and highlight opportunities and weaknesses. Regular measurement of tourism competitiveness can also help to prevent tourism risks and to indicate the fulfillment of long-term strategic aims. The OECD rating system also includes the view of tourists. The measurement framework comprises three types of indicator that can be applied to measure competitiveness in tourism - 11 core indicators and 9 additional indicators ( 5 supplementary indicators and 4 future development indicators). Countries should use the basic indicators for specific evaluations, including additional indicators if absolutely necessary. The overview of all indicators is shown in Figure 2 below.

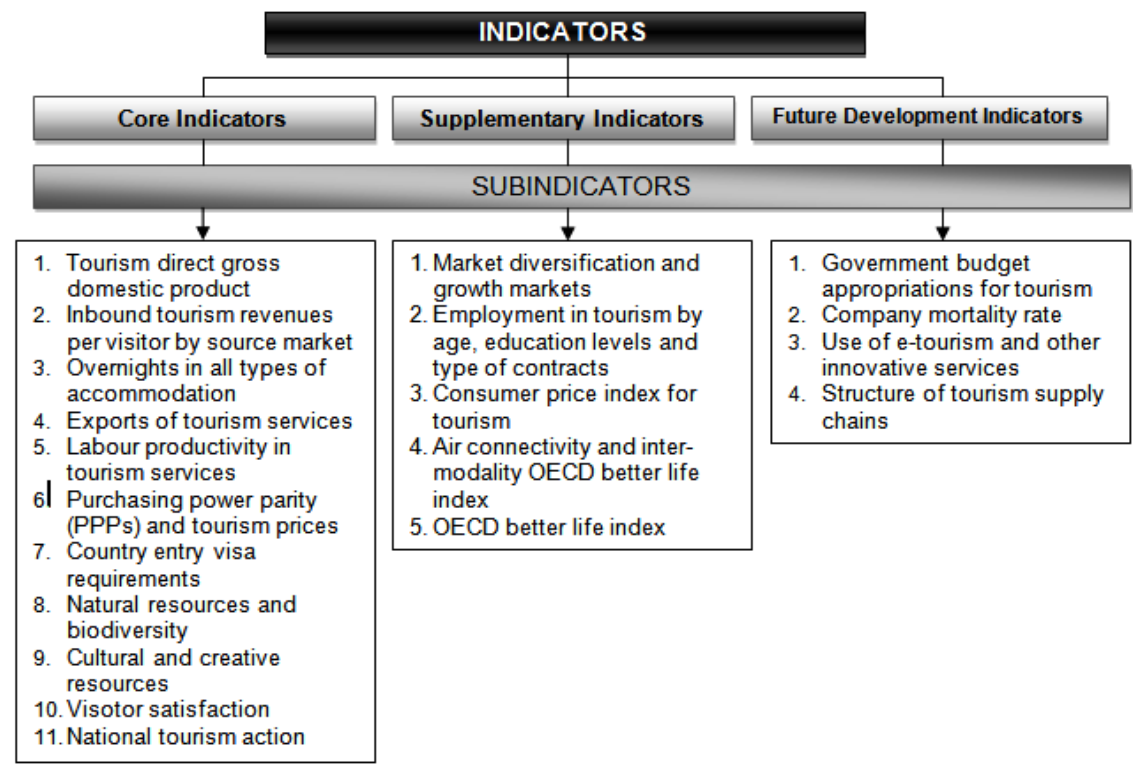

Figure 2. List of indicators for measuring competitiveness in tourism (Source: Dupeyras \& Mac Callum, 2013)

In comparing both competitiveness indexes, the main difference is found in the aim methodology. While the aim of the TTCI index is to provide a ranking of countries from the most competitive to the least competitive, the OECD indicators serve as a tool for governments to analyse strengths and weaknesses of the competitiveness in tourism. Another difference consists in the number of indicators that indexes consist of. The TTCI index consists of 90 indicators and the OECD index consist of 20 indicators, 9 of which are not compulsory. The last difference is the fact that OECD indicators are exclusively focused on economic output in while TTCI indicator is not.

\section{CURRENT CONDITIONS IN TOURISM}

The position of tourism development within the EU is monitored by the Eurostat. The Statistical classification of Economic Activities in the European Community, abbreviated as NACE, is applied as a classification of economic activities within in EU. Eurostat uses classification of economic activities called NACE Rev. 2, according to which the following sections correspond to tourism (see Eurostat - Methodologies and Working Papers, 2008): 
- Section H - Transportation and storage,

- Section I - Accommodation and food service activities,

- Section N - Administrative and support service activities.

The Tourism Satellite Account (TSA) monitoring by UNWTO is based on the cooperation of international organizations that set standards to identify the industry's real contribution - and is used to measure the overall economic contribution of tourism. The TSA's main outputs include employment in the tourism industries, share of gross domestic product, the relationship between tourism and capital investment and the impact on the country's balance of payments. Since 2000, the European Commission has launched a number of initiatives to encourage Member States to compile TSA, but this activity is not compulsory. The Directorate-General for Internal Market, Industry, Entrepreneurship and SMEs (DG GROW) disbursed three rounds of grants and the Member States and EFTA (European Free Trade Association) member countries (Iceland, Liechtenstein, Norway and Switzerland) were invited to submit available TSA data in 2010, 2013 and 2016. TSA indicators were voluntarily submitted by 19 countries in the latest edition (2016) - 17 Member States and 2 EFTA countries. Compared to the previous edition (2013), fewer countries participated - in particular some larger countries such as Germany, Italy and the UK are missing. For this reason, the results cannot be deemed representative for the EU as a whole (Tourism Satellite Accounts in Europe, 2016).

Economic tourism asset can be monitored by using Eurostat balance of payments and structural statistics. The balance of payments monitors the ratio of international travel \& tourism revenues to gross domestic product (GDP). In 2016, the highest ratio was identified in Malta (15.39 \%) and Croatia (10.21\%), while Slovakia recorded an indicated ratio of $2.41 \%$. The EU's average scored rank $4.90 \%$. In absolute numbers, Spain had the highest income $(54,660$ million EUR), followed by the UK $(37,413$ million EUR) and Italy $(36,358$ million EUR). In 2016, the tourism revenues in Slovakia amounted to 2,483 million EUR (The Travel \& Tourism Competitiveness Report, 2017).

According to WEF, in 2016, Europe was once again the region with the strongest overall Travel \& Tourism competitiveness performance, attracting 620 million of the 1.2 billion international visitors (representing more than $51 \%$ of all international arrivals). While the region continues to improve, it does so at a slower rate than other less mature destinations. However, to date, Europe remains the largest Travel \& Tourism market, the second largest and rapidly growing market and the most visited destination all over the world (The Travel \& Tourism Competitiveness Report, 2017). The results of the TTCI 2017 indicated that Spain maintains the $1^{\text {st }}$ place globally in the global Travel \& Tourism competitiveness index. In all, Europe boasts 6 of the 10 most competitive countries in the Travel \& Tourism sector (within all 136 economies covered this year) - Spain, France, Germany, United Kingdom, Italy and Switzerland). The other four European countries are placed in the second ten and other five European countries are sustained in the third ten of the best evaluate countries. The country with the least ranking is Romania at the $68^{\text {th }}$ position (Table 1). From Table 1, a comparison of rankings in 2017 to those in 2015 indicate that Cyprus had the most significant decline in position (from $36^{\text {th }}$ to $52^{\text {nd }}$ rank), representing a decrease of 0.23 points. Finland, had the $2^{\text {nd }}$ highest decline in position, moving to the $33^{\text {rd }}$ position, down 11 positions from 2015 (i. e. from $22^{\text {nd }}$ to $33^{\text {rd }}$ rank), representing a decrease of 0.07 points. Conversely, Greece made the most impressive climb, moving 7 places (from $31^{\text {st }}$ rank to achieve the $24^{\text {th }}$ position) in the global ranking; representing an increase of 0.15 points. Bulgaria recorded the $2^{\text {nd }}$ best improvement in position (from $49^{\text {th }}$ to $45^{\text {th }}$ rank) - a 0.09 points increase, according to the TTCI indicator.

According to the WEF data (based on data of TSA, UNWTO, OECD, Eurostat, WTTC) in 2016, Slovakia recorded an overall of 6,316,000 international tourist arrivals. 
Competitiveness Analysis of Tourism in the European Union and in the Slovakia

Table 1. Ranking of EU countries according TTCI indicator 2017 within around the world (136 economies) (Data source: processing according The Travel \& Tourism Competitiveness Report, 2017)

\begin{tabular}{|l|c|c|c|l|c|c|c|}
\hline $\begin{array}{c}\text { Country/ } \\
\text { Economy }\end{array}$ & $\begin{array}{c}\text { TTCI } \\
\text { score }\end{array}$ & Rank & $\begin{array}{c}\text { Change } \\
\text { since 2015 }\end{array}$ & $\begin{array}{c}\text { Country/ } \\
\text { Economy }\end{array}$ & $\begin{array}{c}\text { TTCI } \\
\text { score }\end{array}$ & Rank & $\begin{array}{c}\text { Change } \\
\text { since 2015 }\end{array}$ \\
\hline Spain & 5.43 & 1. & 0 & Denmark & 4.43 & 31. & -4 \\
\hline France & 5.32 & 2. & 0 & Croatia & 4.42 & 32. & 1 \\
\hline Germany & 5.28 & 3. & 0 & Finland & 4.40 & 33. & -11 \\
\hline United Kingdom & 5.20 & 5. & 0 & Estonia & 4.23 & 37. & 1 \\
\hline Italy & 4.99 & 8. & 0 & Czech Republic & 4.22 & 39. & -2 \\
\hline Austria & 4.86 & 12. & 0 & Slovenia & 4.18 & 41. & -2 \\
\hline Portugal & 4.74 & 14. & 1 & Bulgaria & 4.14 & 45. & 4 \\
\hline Netherlands & 4.64 & 17. & -3 & Poland & 4.11 & 46. & 1 \\
\hline Norway & 4.64 & 18. & 2 & Hungary & 4.06 & 49. & -8 \\
\hline Sweden & 4.55 & 20. & 3 & Cyprus & 4.02 & 52. & -16 \\
\hline Belgium & 4.54 & 21. & 0 & Latvia & 3.97 & 54. & -1 \\
\hline Ireland & 4.53 & 23. & -4 & Lithuania & 3.91 & 56. & 3 \\
\hline Greece & 4.51 & 24 & 7 & Slovak Republic & $\mathbf{3 . 9 0}$ & $\mathbf{5 9 .}$ & $\mathbf{2}$ \\
\hline Luxembourg & 4.49 & 208. & -2 & Romania & 3.78 & 68. & -2 \\
\hline
\end{tabular}

Table 2. Evaluation of Slovakia according to TTCI Report in 2015 and 2017

(Data source: Study results based on The Travel \& Tourism Competitiveness Report, 2017)

\begin{tabular}{|l|c|c|c|c|c|}
\hline \multicolumn{1}{|c|}{ Sub-indexes (1-4) and Pillars (1- 14) } & $\begin{array}{c}\text { TTCI } \\
\text { Score 2015 }\end{array}$ & $\begin{array}{c}\text { Rank } \\
\mathbf{2 0 1 5}\end{array}$ & $\begin{array}{c}\text { TTCI } \\
\text { score 2017 }\end{array}$ & $\begin{array}{c}\text { Rank } \\
\mathbf{2 0 1 7}\end{array}$ & $\begin{array}{c}\text { Change } \\
\text { since 2015 }\end{array}$ \\
\hline 1. Enabling environment & $\mathbf{5 . 1 4}$ & & $\mathbf{5 . 2 4}$ & & $\uparrow$ \\
\hline Business Environment & 3.92 & 25. & 4.01 & 27. & $\downarrow$ \\
\hline Safety and Security & 5.55 & 23. & 5.61 & 23. & - \\
\hline Health and Hygiene & 6.42 & 10. & 6.50 & 9. & $\uparrow$ \\
\hline Human Resources and Labour Market & 4.75 & 20. & 4.70 & 27. & $\downarrow$ \\
\hline ICT Readiness & 5.05 & 20. & 5.37 & 20. & - \\
\hline 2. T\&T Policy and Enabling Conditions & $\mathbf{4 . 2 3}$ & & $\mathbf{4 . 4 5}$ & & $\uparrow$ \\
\hline Prioritization of Travel\&Tourism & 4.04 & 27. & 4.08 & 27. & - \\
\hline International Openness & 3.89 & 23. & 3.91 & 22. & $\uparrow$ \\
\hline Price competitiveness & 4.51 & 8. & 4.96 & 6. & $\uparrow$ \\
\hline Environmental Sustainability & 4.49 & 17. & 4.84 & 14. & $\uparrow$ \\
\hline 3. Infrastructure & $\mathbf{3 . 6 5}$ & & $\mathbf{3 . 4 3}$ & & $\downarrow$ \\
\hline Air Transport Infrastructure & 1.78 & 27. & 1.75 & 27. & - \\
\hline Ground and Port Infrastructure & 4.22 & 21. & 4.19 & 19. & $\uparrow$ \\
\hline Tourist Service Infrastructure & 4.94 & 22. & 4.34 & 26. & $\downarrow$ \\
\hline 4. Natural and Cultural Resources & $\mathbf{2 . 3 6}$ & & $\mathbf{2 . 4 8}$ & & $\uparrow$ \\
\hline Natural Resources & 3.31 & 12. & 3.43 & 11. & $\uparrow$ \\
\hline Cultural Resources and Business Travel & 1.42 & 25. & 1.53 & 26. & $\downarrow$ \\
\hline TOTAL & $\mathbf{3 . 8 4}$ & $\mathbf{2 7 .}$ & $\mathbf{3 . 9 0}$ & $\mathbf{2 7 .}$ & - \\
\hline
\end{tabular}

International tourism inbound revenues was 2.363 million USD. Travel \& Tourism industry GDP value was 2.034 million USD; representing $2.4 \%$ of the total economy The Travel \& Tourism industry employment share in the total economy was $2.5 \%$, which, represents 58,876 employees employed in tourism in 2016. Slovakia ranked $27^{\text {th }}$ position 
among the EU 28 member countries according to TTCI 2017 ranking (value of TTCI at level 3.90). In comparison to 2015, this is an increase of index value by 0.06 points (3.84). Despite this, Slovakia still remains at an unsatisfactory position. Results for individual sub-indexes and individual pillars for Slovakia are shown in Table 2.

In Slovakia, the framework pillar with the highest ranking, according to Table 2, is the Price competitiveness pillar ( $8^{\text {th }}$ position in 2015 and $6^{\text {th }}$ position in 2017), which falls under the Travel \& Tourism Policy and Enabling Conditions sub-index. In addition, Slovakia also achieved very good results in subindex 1 (Enabling environment), within a pillar called Health and Hygiene. This was due, in particular, to the high percentage of people who have access to drinking water, the number of doctors per 1,000 inhabitants and the number of hospital beds (The Travel \& Tourism Competitiveness Report, 2017).

The worst results were found within the indicators of the Business environment pillar (average $26^{\text {th }}$ position), Prioritization of Travel \& Tourism (last position in both monitored years) and Air Transport Infrastructure (last position in both monitored years) in comparison EU members countries. Slovakia has fallen behind within the Business environment pillar, in the following indicators - efficiency of legal framework in settling disputes; the time required to deal with construction permits; and the effect of taxation on incentives to work. The WEF identified shortcomings in many other indicators as well. Slovakia also scored the worst positions in the following indicators - hiring and firing practices; ease of finding skilled employees; government prioritization of the travel and tourism industry; effectiveness of marketing and branding to attract tourists; fuel price levels; aircraft departures; number of operating airlines, amongst others (The Travel \& Tourism Competitiveness Report, 2017).

\section{DATA AND METHODOLOGY}

The main aim of this paper was to explore and analyse tourism competitiveness in EU member countries (28), with focus on Slovakia, based on the Travel \& Tourism Competitiveness Index (TTCI) methodology; and to identify the factors that affect Slovakia competitive position in this ranking, and their specific impacts. Benchmarking of selected countries was realized for the period of 2015 and 2017. The study also includes an analysis of the competitiveness of the EU countries based on own assessment using cluster analysis and three selected macroeconomic indicators - tourism revenues, tourism expenditures and gross domestic product per capita in tourism. The secondary aim of this paper is to evaluate whether or not the ranking of EU members countries based on TTCI evaluation is influenced by selected macroeconomic indicators. This analysis was carried out using secondary data published by the WEF, the World Bank and Eurostat for the period of 2015 and 2017. Cluster analysis was carried out on data obtained in 2015 only as, data reported for 2017 did not cover the indicators of each EU country.

The linear relationship between the selected indicators was estimated using the Kendall correlation coefficient calculated thus (Král' et al., 2009):

$$
r_{K}=\frac{n_{c}-n_{d}}{n(n-1) / 2}
$$

where: $\quad n$ - number of observations of pair of variables,

$n_{c}$ - number of discordant pairs,

$n_{d}$ - number of concordant pairs.

Integration processes of the production participants are considered to be a factor of economic development. Cluster (being an integration - network economic system) is recognized as an efficient tool for the development of production industry. The formation 
and development of the tourist clusters are unique in comparison with the clusters in industries and other production spheres (Gritsay, Kulagina, Lukina, Proncheva, 2018). The individual countries in the EU are assigned to clusters/groups using the Ward method and the Euclidean distance among individual countries (Král' et al., 2009):

$$
d_{i j}=\sqrt{\sum_{k=1}^{K}\left(x_{i k}-x_{j k}\right)^{2}}
$$

where $\quad \mathrm{K}$ - number of variables,

$\mathrm{x}_{\mathrm{ik}}$ - i-th coordinate in dimension "k",

$\mathrm{x} \mathrm{jk}$ - j-th coordinate in dimension " $k "$.

The Kruskal-Wallis Test, as a non-parametric method, was used to assess whether samples originate from the same distribution. It is used for comparing two or more independent samples of equal or different sample sizes. In this study, the differences between created samples and tourism competitiveness of EU countries represented by TTCI indicator are monitored. The formula for the Kruskal-Wallis Test is (Král' et al., 2009):

$$
K W=\frac{12}{n(n-1)} \sum_{i=1}^{I} \frac{T_{i}^{2}}{n_{i}}-3(n+1)
$$

where:

$$
\mathrm{n} \text { - number of observations, }
$$

$n_{i}$ - number of observations in i-th group,

$T_{i}^{2}$ - total number of order in i-th group.

The quantified results were graphically represented by a correlation chart or a frequently used dendrogram (Adamišin et al., 2015). The statistical data processing was realized by using MS Excel, Statistica13 and Statgraphics.

\section{RESULTS AND DISCUSSION}

This section describes the results of the relationship between selected indicators within EU countries monitored by Kendall correlation coefficients. Results are shown in the Figure 3. Based on the correlation coefficient values among individual indicators, a statistically significant relationship was confirmed. The correlation coefficients presented varying correlation intensities. Medium linear correlation was confirmed between tourism revenues and tourism expenditures.

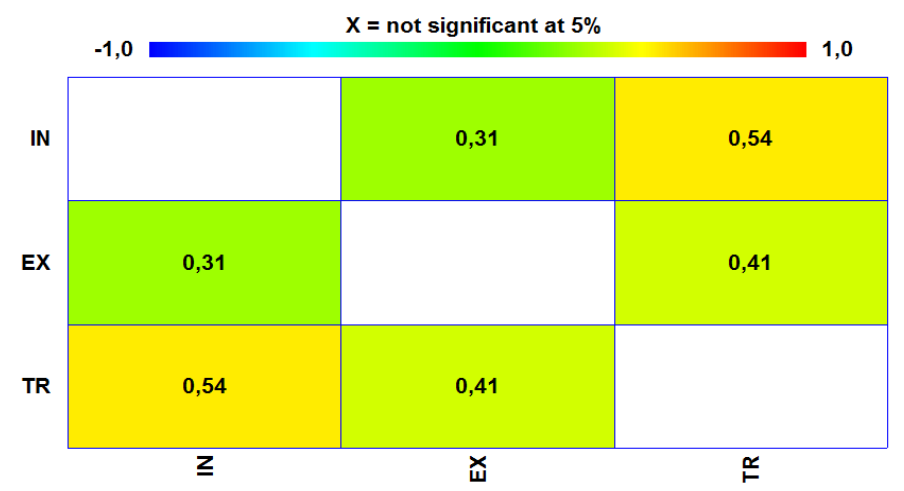

Figure 3. Results of correlation analysis among selected indicators within EU countries 
where $\quad$ IN - tourism revenues per capita,

EX - tourism expenditures per capita,

TR - gross domestic product in tourism per capita.

A similar relationship was also confirmed between tourism expenditures and GDP in tourism. Correlation coefficients also confirmed statistically strong significant relationship between GDP in tourism and tourism revenues. All indicators relationships were identified at the significance level of $\mathrm{p}<0.05$.

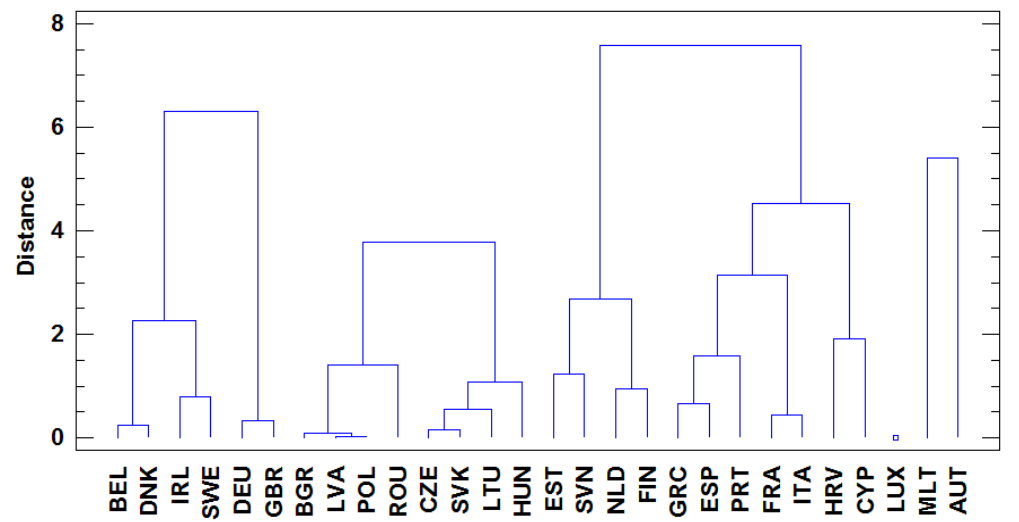

Figure 4. Dendrogram of EU countries in 2015

In the next section, results of the (more in-depth) cluster analysis of EU member countries are presented. In total, 5 clusters were generated by applying all the abovementioned indicators (Figure 4). Based on a realized cluster analysis three significant clusters/groups of countries were created. They are:

a) Cluster 1 - "Tourism balanced countries" - which have all required values for all monitored indicators (including countries like Belgium, Denmark, Ireland, Sweden, Germany and the United Kingdom),

b) Cluster 2 - "Tourism lagged countries" - which have the lowest values for all monitored indicators (including countries like Bulgaria, Lithuania, Poland, Romania, Czech Republic, Slovakia, Latvia and Hungary),

c) Cluster 3 - "Tourism receipted countries" - with a marked positive score between country's revenues and expenditures (including countries like Estonia, Greece, Spain, France, Croatia, Italy, Cyprus, Netherlands, Portugal, Slovenia and Finland). As the largest group/cluster was identified the 3rd cluster, that it is mainly characterized by low expenditures per capita. Centroids of individual clusters are shown in Table 3.

Table 3. Centroids of created clusters in 2015

\begin{tabular}{|c|c|c|c|}
\hline Cluster & IN & EX & TR \\
\hline 1 & 844.13 & 1190.22 & 1199.86 \\
\hline 2 & 365.49 & 246.03 & 301.31 \\
\hline 3 & 1080.63 & 505.37 & 986.54 \\
\hline 4 & 7041.82 & 5432.73 & 1686.21 \\
\hline 5 & 2411.36 & 866.49 & 2729.54 \\
\hline
\end{tabular}

Table 4. Results of correlation analysis among TTCI and selected indicators

\begin{tabular}{|l|c|c|c|}
\hline & IN & EX & TOUR \\
\hline rK & 0.0416 & 0.0260 & 0.0025 \\
\hline p-value & 0.8288 & 0.8925 & 0.9898 \\
\hline
\end{tabular}


Based on previous analysis (in section Current conditions in tourism), we can state that Luxembourg showed appreciably high tourism revenues and expenditures. This implies that this country cannot be assigned to the created clusters with regard of overall country results. The next part of this paper focuses on monitoring the relationship between selected indicators and the TTCI indicator used to measure countries' tourism competitiveness. The TTCI indicator does not correlate linearly with any of the selected indicators (Table 4). Based on correlations, it cannot be stated, whether the increase/decrease of the TTCI index causes linearly increase/decrease of tourism revenues, tourism expenditures or gross domestic product per capita in tourism.

Given that the linear relationship between TTCI indicator and the three selected macroeconomic indicators has not been confirmed. The next part of this study was devoted to analyses of tourism competitiveness within EU countries using 5 created clusters. The results are presented in Figure 5. Based on the graphical comparison and Kruskal-Wallis test results $(\mathrm{Q}=1.278, \mathrm{r}=0.864)$, we can conclude that tourism competitiveness expressed by the TTCI index is not determined by the created clusters.

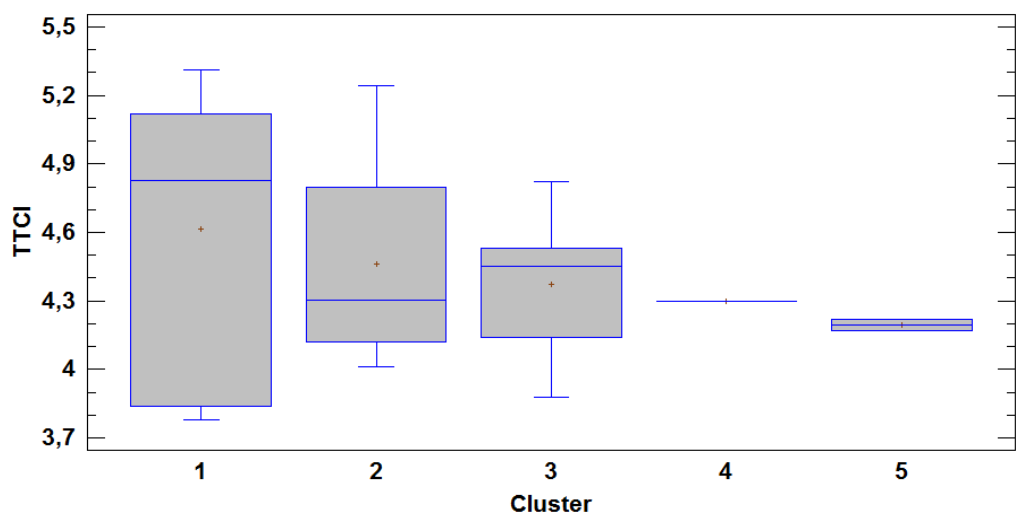

Figure 5. Comparison of TTCI within created clusters

\section{CONCLUSION}

Tourism is recognized as one for the key sectors for development in all countries; as well as a major source of income, jobs and wealth creation. It also plays a wider role in promoting the image and international perception of a country as well as influencing complementary domestic policies. This range of influence and importance creates challenges in measuring competitiveness in tourism (Dupeyras \& Mac Callum OECD Tourism Papers, 2013). This study had several aims: the main aim was to analyze the tourism competitiveness of EU member countries (28), with specific focus on Slovakia, based on the TTCI indicator for the period of 2015 and 2017. The competitiveness reports in 2015 and 2017 confirmed that Europe is still regarded as the region with the highest number of the most competitive economies in the tourism sector. Based on the TTCI indicator' results in 2017, we concluded that Spain maintained the $1^{\text {st }}$ place globally in the global Travel \& Tourism competitiveness index. Europe boasts 6 of the 10 most competitive countries in this sector (within all 136 economies covered this year) - Spain, France, Germany, United Kingdom, Italy and Switzerland). Analyses also shown that four other European countries are placed in the second ten and other five European countries are sustained in the third ten of the best evaluate countries. Although UNWTO predicts that the share of international arrivals to Europe will decrease by 2030 (from the current $51 \%$ to predicted $41 \%$ ), Europe as a competitive region will still attracts the visitors from around the world. In accordance to TTCI 2017 ranking, Slovakia scored $59^{\text {th }}$ position among the 
countries from around the world (136 economies). When comparing EU countries, Slovakia holds the $27^{\text {th }}$ position. In spite of the positive change in ranking between the period 2015 and 2017 (an increase of index value by 0.06 points), Slovakia still remains in a dire position in this ranking. Based on the results of cluster analysis, we concluded that the best rated countries were Malta and Austria. Both countries scored the highest revenues per capita (with the exception of Luxembourg) and the highest values of tourism competitiveness indicator. A more in-depth analysis of the sub-indexes, pillars and indicators, which TTCI indicator consists of, we found out that the weak competitiveness position of Slovakia in tourism affects factors (indicators) - efficiency of legal framework in settling disputes; the time required to deal with construction permits; the effect of taxation on incentives on work hiring and firing practices; ease of finding skilled employees; government prioritization of travel and tourism industry; effectiveness of marketing and branding to attract tourists; fuel price levels, particulate matter concentration; aircraft departures; and number of operating airlines. All these indicators result in an unsatisfactory competitive evaluation of Slovakia in tourism, indicating the importance of paying attention to them in the future. Results of created cluster analysis confirmed three significant clusters/groups of countries which were divided into the following sections:

a) Cluster 1 called "Tourism balanced countries" - required values of selected indicators,

b) Cluster 2 called "Tourism lagged countries" - the lowest values of selected indicators,

c) Cluster 3 called "Tourism receipted countries" - revenues are higher than expenditures.

Based on cumulative findings, we can conclude that the TTCI indicator is not influenced by revenues, expenditures or GDP per capita in tourism. In addition, we can state, that evaluation of country by using TTCI indicator is not determined by membership to any of created clusters.

\section{Acknowledgements}

This paper was prepared as part of the grant scheme VEGA no. 1/0791/16 Modern approaches to improving enterprise performance and competitiveness using the innovative model - Enterprise Performance Model to streamline Management DecisionMaking Processes.

\section{REFERENCES}

Adamišin, P., Vavrek, R., \& Pukala, R. (2015). Cluster analysis of Central and Southeast Europe via selected indicators of sustainable development. Environmental economics, education and accreditation in geosciences: ecology, economics, education and legislation. vol. 3, Conference proceedings: 15th international multidisciplinary scientific geoconference SGEM 2015. p. 135-140.

Baiburiev, R., David, L., Abdreyeva, S., Zhakupova, A., \& Artemyev, A. (2018). Impacts of Tourism Activities on Economy of Kazakhstan. GeoJournal of Tourism and Geosites, 22(2): 480-488.

Barbosa, L., Oliveira, C., \& Rezende, C. (2010). Competitiveness of tourist destinations: the study of 65 key destinations for the development of regional tourism. Revista de Administracao Pública, 44(5): 1067 - 1095.

Butnaru, G., I., \& Niță, V. (2016). European Union and Romanian Tourism - $\beta$ and $\sigma$ Convergence in the Economic Development Regions of Romania. Amfiteatru Economic, 18(42): 369-384.

Cibinskienea, A., \& Snieskieneb, G. (2015). Evaluation of city tourism competitiveness. 20th International Scientific Conference Economics and Management - 2015 (ICEM-2015). Procedia - Social and Behavioral Sciences 213, p. $105-110$.

Cvelbar, L., K., Dwyer, L., \& Koman, M. (2015). Drivers of Destination Competitiveness in Tourism. Journal of Travel Research, 55(8): 1041-1050.

Čerović, S., Knežević, M., \& Pavlović, D. (2016). The Effects of Tourism on the GDP of Macedonia, Montenegro and Serbia. The Process of European Integration, Amfiteatru Economic, 18(42):407-422.

Dupeyras, A., \& MacCallum, N. (2013). Indicators for Measuring Competitiveness in Tourism: A Guidance Document. OECD Document Papers 2013/o2, [online] Available at: http://www.oecd.org/cfe/tourism/ Indicators\%2ofor\%2oMeasuring\%20Competitiveness\%2oin\%20Tourism.pdf [Accessed 12 February 2018].

Gabor, M., R., Contiu, C., L., \& Oltean, F.D. (2012). A Comparative Analysis Regarding European Tourism Competitiveness: Emerging Versus Developed Markets. Procedia Economics and Finance, vol. 3, p. 361-366. Available at: https://www.sciencedirect. com/science/ article/pii/S2212567112001657 [Accessed 08.04.2018]. 
Hanafiah, M., H., Hemdi, M., A., \& Ahmad, I. (2014). Tourism Destination Competitiveness. SAGE Journals, 22(3): 629-636.

Gritsay, M., Kulagina, E., Lukina, O., \& Proncheva, O. (2018). Key indicators of Clusterization Potential in Regional Tourism, GeoJournal of Tourism and Geosites. 22(2): 297-306.

Kadiyali, V., \& Kosová, R. (2013). Inter-industry employment spillovers from tourism inflows. Regional Science and Urban Economics, 43(2): 272-281.

Khan, S., A., R., Qianli, D., SongoBo, W., Zaman, K., \& Zhang, Y. (2017). Travel and tourism competitiveness index: The impact of air transportation, railways transportation, travel and transport services on international inbound and outbound tourism. Journal of Air Transport Management, vol. 58, p. 125-134. Available at: https://www.sciencedirect.com/science/ article/abs/pii/So969699716301351 [Accessed 08.04.2018].

Kolosinska, M., Petrashchak, O., Kolosinskyi, I., \& Katana, A. (2018). Tourism sector in transition economy on example of Ukraine: Determinants of Competitiveness. GeoJournal of Tourism and Geosites. 21(1): 239-252.

Kral, P., Kanderova, M., Kascakova, A., Nedelova, G., \& Valencakova, V. (2009). Multidimensional statistical methods focusing on solving problems of economic practice. $1^{\text {st }}$ edition, ISBN 978-80-8083-840-9.

Krstic, B., Jovanovic, S., Jankovic-Millic, V., \& Stanisic, T. (2016). Examination of travel and tourism competitiveness contribution to national economy competitiveness of sub-Saharan Africa countries. Journal Development Sourther Africa, 33 (4): pp. 470-485.

Krstić, B., Radivojević, V., \& Stanišić, T. (2016). Determinants of CEE Countries' Tourism Competitiveness: A Benchmarking Study. Management. 21(80): 11-21. Available at: http://management.fon.bg.ac.rs/index. $\mathrm{php} / \mathrm{mng} /$ article/view/26 [Accessed 8 April 2018].

Kubickova, M., \& Li, H. (2017). Tourism Competitiveness, Government and Tourism Area Life Cycle (TALC) Model: The Evaluation of Costa Rica, Guatemala and Honduras. International Journal of Tourism Research, 19(2): 223-234.

Li, H., Chen, J., L., Li, G., \& Goh, C. (2016). Tourism and regional income inequality: Evidence from China. Annals of Tourism Research, vol. 58, p. 81-99.

Nica, A., M. (2015). Cultural heritage and Tourism Competitiveness in Central and Eastern Europe. International Journal of Economic Practices \& Theories. 5(3): 248-255.

Tatar, C.F., Herman, G.V., \& Gozner, M. (2018). Tourist guides' contribution to sustainability in Romania. GeoJournal of Tourism and Geosites. 21(1): 282-287.

Xing, L., I., Jing, M., A., \& Sun, K., Q. (2014). Study on cultural heritage tourism competitiveness of Lushan mountain based on factor analysis. Resource Development \& Market.

*** Eurostat. (2018). Travel receipts and expenditure in balance of payments. [online]. Available at:http://ec.europa.eu/eurostat/statisticsexplained/index.php/File: Travel_receipts_and_expenditure_ in_balance_of_payments, 2011\%E2\%80\%932016.png [Accessed 15 February 2018].

*** Eurostat. (2018). Annual detailed enterprise statistics for services /NACE Rev, 2 H-N and S95, [online] Available at: http://appsso.eurostat.ec.europa.eu/nui/show.do?dataset=sbs_na _1a_se_r2\&lang=en [Accessed 15 February 2018].

*** Eurostat. (2018). Statistical Reports Tourism Satelitte Acounts in Europe 2016 edition, [online]. Available at: http://ec.europa.eu/eurostat/documents/7870049/7880233/KS-FT-17-002-EN-N.pdf/1070ebdcb9e1-4a93-abb8-cecd83d4of68 [Accessed 15 February 2018].

*** Eurostat. (2008). Methodologies and Working papers. NACE Rev. 2. Statistical classification of economic activities in the European community, [online]. Available at: http://ec.europa.eu/eurostat/documents/3859598 /5902521/KS-RA-07-015EN.PDF/dd5443f5-b886-40e4-920d-9dfo359off91?version=1.o[Accessed 15.02.2018].

*** Organisation for Economic Co-operation and Development - OECD. (2018). Secretary-General's Report to Ministers. Available at: https://read.oecd-ilibrary.org/economics/secretary-general-s-report-toministers-2018_sg_report-2018-en\#page1

*** The World Bank. (2018). Travel \& Tourism direct contribution to GDP. [online]. Available at: https://tcdata360.worldbank.org/indicators/tot.direct.gdp?country=SVK\&indicator=24648\&viz=line_c hart\&years=1995,2027 [Accessed 15 February 2018].

*** World Tourism Organization. (2018). Tourism Towards 2030/Global Overview. [online]. Available at: http://www.wise.co.th/wise/Knowledge_Bank/References/Tourism/UNWTO_Tourism_Toward_203 .pdf [Accessed 15 February 2018].

*** World Economic Forum. (2018). Insight Report. The Travel \& Tourism Competitiveness Report 2017. Paving the way for amore substainable and inclusive futur. [online]. Available at: http://www3.weforum. org/docs/WEF_TTCR_2017_web_0401.pdf [Accessed 15 February 2018].

*** World Economic Forum. (2018). Insight Report. The Travel \& Tourism Competitiveness Report 2015. Growth through Shocks. [online]. Available at: http://www3.weforum.org/docs/TT15 /WEF_Global_ Travel\& Tourism_Report_2015.pdf [Accessed 15 February 2018].

Submitted:

o8.08.2018
Revised:

02.11.2018
Accepted and published online

05.11.2018 